\title{
EFEKTIVITAS LAYANAN KONSELING KELOMPOK MENGGUNAKAN TEKNIK PROBLEM SOLVING DALAM MENURUNKAN PERILAKU MEMBOLOS SISWA
}

M. Fatchurahman * Universitas Muhammadiyah Palangkaraya

\section{Dina Fariza Triyani Syarif}

Universitas Muhammadiyah Palangkaraya

\section{Siti Turohmi}

Universitas Muhammadiyah Palangkaraya

\begin{abstract}
THE EFFECTIVENESS OF GROUP COUNSELING SERVICES USING PROBLEM SOLVING TECHNIQUES IN REDUCING STUDENTS TRUANT BEHAVIOR. Various problems faced by the student counselor at school. One of the problem is truant during the school hours. Truant behavior of the student with a wide variety of reasons as a form of defending himself in order not to get a penalty. This research was conducted in order to determine the effectiveness of group counseling services to problem solving techniques in reducing truant behavior among students of class X SMAN 2 Palangkaraya. This type of research is the approach of the Pre-Experiment without any form of class control with One-group pretest-posttest design. Subjects were students of class XI in High School Mathematics 2 Palangkaraya of 8 people identified as having truant. Research data collection using a scale. Data analysis using Paired Samples T Test with rocky SPSS software version 20.00 . The results showed that the group counseling services to problem solving technique was effective in reducing the truant behavior of students at SMA Negeri 2 Palangkaraya.
\end{abstract}

KEYWORDS: Group Counseling, Problem Solving Techniques, Truant.

* Corresponding Author: Program Studi Bimbingan dan Konseling, FKIP Universitas Muhammadiyah Palangkaraya; Jl. RTA. Milono KM 1, 5, Langkai, Pahandut, Kota Palangka Raya, Kalimantan Tengah, Indonesia 73111; Email: mfatchurahman789@gmail.com

Article History: Received: 28-10-2017; Revised: 20-11-2017; Accepted: 02-1-2018

Permalink: http://ijec.ejournal.id/index.php/counseling/article/view/18

How to cite (APA): Fatchurahman, M., Syarif, D. F. T., \& Turohmi, S. (2018). Efektivitas layanan konseling kelompok menggunakan teknik problem solving dalam menurunkan perilaku membolos siswa. Indonesian Journal of Educational Counseling, 2(1), 55-68.

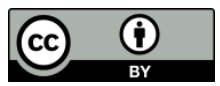

This is an open access article distributed under the terms of the Creative Commons Attribution 4.0 Internationa License, which permits unrestricted use, distribution, and reproduction in any medium, provided the original work is properly cited. @ 2018, M. Fatchurahman, Dina Fariza Triyani Syarif, Siti Turohmi.

\section{PENDAHULUAN}

Pelayanan bimbingan dan konseling yang sedang dikembangkan di Indonesia adalah bimbingan dan konseling yang berorientasi pada perkembangan, yaitu sebuah pelayanan yang diberikan lebih mengutamakan dan mengedepankan berbagai bentuk dan jenis layanan yang memungkinkan siswa dapat mengurangi perilaku bermasalah, sehingga dapat berkembangnya segenap potensi yang dimiliki peserta didik. 
Konselor dalam menangani berbagai permasalahan siswa di sekolah, dapat berkolaborasi dengan seluruh komponen yang ada di sekolah. Tugas-tugas konselor dalam usaha membantu siswa untuk mengentaskan permasalahannya secara umum dikelompokkan ke dalam 3 (tiga) bidang yaitu bidang pribadi-sosial, bidang akademik dan bidang karier. Nurihsan (2006) mengatakan bahwa terdapat empat jenis masalah yang terdapat pada individu, masalah-masalah tersebut antara lain: masalah akademik, masalah sosial pribadi, masalah karier dan masalah keluarga.

Persoalan dalam belajar merupakan suatu masalah yang dengan kondisi tertentu dialami oleh siswa, sehingga dapat menghambat kelancaran proses belajarnya. Masalah-masalah belajar ini tidak hanya dialami oleh para siswa yang lambat dalam belajarnya, tetapi juga dapat menimpa para siswa yang pandai atau cerdas (Badarudin, 2011). Sedangkan bidang karier merupakan suatu kondisi yang dihadapi siswa ketika tidak dapat menentukan alternatif dalam usaha pengembangan karier yang dilakukan secara cermat. Hal ini akan dapat menimbulkan masalah karier pada siswa. Karena itu masalah karier yang dihadapi siswa perlu mendapat perhatian, sehingga ia mampu dalam merencanakan masa depannya dengan baik; dalam mengambilan atau pemilihan jurusan, pemilihan pekerjaan setelah lulus sekolah.

Dalam bidang bimbingan pribadi-sosial yang diberikan kepada siswa merupakan pemberian bantuan dalam rangka untuk memecahkan permasalahan yang sifatnya pribadi (rahasia) dan sangat kompleks pula. Yusuf (2005) yang mengungkapkan bahwa bimbingan pribadi-sosial adalah bimbingan untuk membantu para individu dalam memecahkan masalah-masalah sosial-pribadi.

Sebagai salah satu bidang garapan pada bimbingan dan konseling di sekolah adalah bidang pribadi-sosial siswa mengenai permasalahan yang sering dihadapi adalah siswa yang sering melakukan membolos pada saat jam pelajaran, ada nya perkelahian antar teman, membuly sesama teman disekolah, melanggar tata tertib yang ada disekolah.

Fenomena yang terjadi di SMA Negeri 2 Palangkaraya berdasarkan hasil observasi dan wawancara dengan konselor, siswanya ketahuan membolos pada saat jam pelajaran berlangsung dengan berbagai alasan seperti halnya dengan alasan izin pulang mengambil tugas yang ketinggalan di rumah dan pada akhirnya peserta didik tidak kembali ke sekolah, izin berpura-pura sakit ke Usaha Kesehatan Sekolah (UKS) yang ternyata di Usaha Kesehatan Sekolah (UKS) peserta hanya ingin bersantai untuk tidur-tiduran dan tidak sakit, peserta didik yang keluar sekolah tanpa meminta surat izin dari sekolah, peserta didik yang memiliki perilaku membolos sehingga dapat mempengaruhi teman-temannya, sampai membolos untuk merokok di luar sekolah. 
Perilaku membolos merupakan tanggapan atau reaksi individu yang terwujud dalam gerakan meninggalkan pelajaran saat jam pelajaran berlangsung dan tidak mengikuti proses belajar mengajar di sekolah (Mahmudah, 2013). Perilaku membolos yang dilakukan siswa dengan bermacam-macam alasan merupakan usaha untuk membela diri mereka agar tidak mendapatkan hukuman yang berat dari sekolahnya atau agar tidak mendapat surat panggilan orang tua serta surat pelanggaran tata tertib. Perilaku membolos ini juga termasuk dalam kategori kenakalan remaja yang terjadi di sekolah dan dapat berakibat buruk pada siswa itu sendiri bahkan akan berakibat buruk juga kepada teman, keluarga dan lingkungan sosialnya.

Kartono (2014) menyatakan bahwa membolos sekolah lalu bergelandangan sepanjang jalan atau bersembunyi di tempat-tempat terpencil sambil melakukan eksperimen dengan bermacam-macam kedurjanaan dan tindak a-susila. Lebih lanjut Kartono menyatakan membolos merupakan perilaku yang melanggar norma-norma sosial sebagai akibat dari proses pengondisian lingkungan yang buruk (Handoko, 2013). Sarwono (2010) menyatakan bahwa kenakalan yang melawan status, misalnya mengingkari status anak sebagai pelajar dengan cara membolos, mengingkari status orang tua dengan cara minggat dari rumah atau membantah perintah mereka, dan sebagainya.

Terjadinya perilaku membolos tersebut secara ekternal dapat terjadi akibat dari jenuhnya siswa terhadap mata pelajaran tertentu didalam kelas yang diakibatkan guru yang mengajar menggunakan pendekatan, model atau metode yang secara konvensional itu-itu saja, seperti ceramah, diskusi dan pemberian tugas. Disamping itu faktor internal siswa juga berpengaruh akibat kuranya perhatian dari orang tua sehingga malas untuk masuk sekolah. Siswa yang membolos ini hampir terjadi di seluruh sekolah, meski jumlah siswa yang membolos pada jam efektif sekolah hanya sedikit dibandingkan dari jumlah siswa yang tidak membolos, namun demikian terlepas sekecil apapun dari jumlah tersebut harus menjadi perhatian bagi semua pihak terutama seluruh komponen di sekolah itu sendiri, sehingga pada akhirnya dapat berefek kepada temantemanya dan dapat merugikan dirinya dan orang lain.

Secara psikologis pada usia antara 15-21 tahun adalah usia pencarian jati diri. Terbukti, siswa yang suka membolos ini seringkali terlibat dengan hal-hal yang cenderung merugikan (Damayanti \& Setiawati, 2013). Karena itu dalam hal ini konselor untuk sesegera mungkin memberikan bantuan berupa layanan bimbingan dan konseling kepada siswa. Salah satu layanan yang diberikan kepada siswa yang membolos tersebut adalah dengan layanan konseling kelompok. 
Para siswa dalam kegiatan konseling kelompok, dapat menceritakan permasalahan-permasalahan apa saja yang dihadapinya yang dapat menyebabkan dirinya menjadi pembolos. Sukardi (2000) dan Kurnanto (2013) menyebutkan bahwa layanan konseling kelompok adalah suatu proses konseling yang dilakukan dalam situasi kelompok, dimana konselor berinteraksi dengan konseli dalam bentuk kelompok yang bersifat dinamis dalam rangka membantu permasalahan yang dihadapi secara bersama-sama sehingga permasalahannya dapat terentaskan secara bersama-sama pula dalam kelompok tersebut.

Selain itu untuk lebih efektifnya pelaksanakan layanan konseling kelompok saja peneliti juga menggunakan teknik problem solving dalam membantu siswa yang teridentifikasi membolos atau pernah membolos, sehingga dapat mengurangi perilaku membolos dan siswa mampu memahami ketika teknik problem solving diterapkan. Menurut Majid (2012) dan Setiawan (2015) yang disimpulkan bahwa teknik problem solving merupakan cara memberikan pengertian dengan menstimulasi anak didik dengan tujuan untuk memperhatikan, menelaah dan berpikir tentang suatu masalah sehingga teridentifikasi, selanjutnya menganalisis masalah tersebut sebagai upaya memecahkan masalah dan akhirnya dapat pelatihan sistematis keterampilan kognitif.

Problem solving sebagai proses perilaku mandiri kognitif dimana seorang individu, pasangan, atau kelompok untuk mencoba mengidentifikasi atau menemukan solusi yang efektif untuk menemukan masalah khusus dalam kehidupan sehari-hari. Lebih khusus, proses perilaku-kognitif (a) membuat tersedia berbagai solusi yang berpotensi efektif untuk masalah tertentu dan (b) meningkatkan kemungkinan memilih solusi yang paling efektif dari antara berbagai alternatif (D'Zurilla \& Goldfried, 1971)

Penelitian Sohrabi, dkk. (2013), Suparmanto (2014) dan Rosidah (2016) yang disimpulkan bahwa penggunaan bimbingan kelompok melalui teknik problem solving tenyata efektif meningkatkan keaktifan dan prestasi belajar siswa, self-efficacy akademik dan penyesuaian diri siswa terisolir. Dalam usaha untuk menurunkan perilaku membolos siswa maka dapat digunkan salah satu layanan konseling kelompok dengan teknik problem solving karena dianggap lebih tepat. Kurnanto (2013) menyatakan bahwa konseling kelompok mempunyai dua fungsi, yaitu fungsi layanan kuratif yang diarahkan untuk mengatasi persoalan yang dialami individu, serta fungsi layanan preventif yang diarahkan untuk mencegah terjadinya persoalan pada diri individu.

Oleh karena itu perilaku siswa seperti membolos tersebut perlu dilakukan alternatif pemecahannya dalam sebuah kelompok, sehingga kemampuannya untuk memecahkan masalah secara bersama-sama dapat ditingkatkan dan akhirnya diharapkan mampu membuat keputusan secara tepat dan benar dan 
siswa tidak lagi untuk melakukan perilaku membolos. Dengan demikian maka penelitian ini dilakukan dengan tujuan untuk mengetahui kefektivan layanan konseling kelompok dengan berbantuan teknik problem solving untuk menurunkan perilaku membolos siswa pada SMA Negeri 2 Palangkaraya.

\section{METODE}

Penelitian ini menggunakan pendekatan eksperimen. Jenis penelitian yang digunakan adalah pendekatan Pre-Eksperiment tanpa ada kelas kontrol dengan bentuk One-Group Pretest-Posttest Design. Subyek penelitian adalah siswa kelas XII IPA di SMA 2 Palangkaraya berjumlah delapan (8) orang yang teridentifikasi memiliki perilaku membolos. Pengumpulan data penelitian menggunakan skala. Skala dikembangkan dari skala Likert dengan kriteria penskoran menurut Sugiyono (2013) dan indikator perilaku membolos dikembangkan berdasarkan pendapat Mahmudah (2013) dan Ichsani (2007). Analisis data untuk mengetahui keefektifan layanan konseling kelompok dengan berbantuan teknik problem solving dalam menurunkan perilaku membolos siswa pada kelas XI MIPA di SMA Negeri 2 Palangkaraya adalah dengan menggunakan Paired Samples $T$ Test. Analisis ini untuk mengetahui terdapat tidaknya tingkat perbedaan siswa sebelum dan sesudah perlakuan terhadap berperilaku membolos.

\section{HASIL DAN PEMBAHASAN}

Hasil pengukuran tingkat perilaku membolos dengan menggunakan skala perilaku membolos saat pre-test dan post-test pada subjek penelitian, sebagaimana pada Tabel 1.

Tabel 1. Hasil Pre-Test dan Post-Test Pada Subjek Penelitian

\begin{tabular}{ccccc}
\hline Peserta didik & Skor pre-test & Kategori & Skor post-test & Kategori \\
\hline LA & 148 & Tinggi & 60 & Sangat rendah \\
\hline EDL & 125 & Sedang & 55 & Sangat rendah \\
\hline AWN & 121 & Sedang & 73 & Rendah \\
\hline RFBB & 154 & Tinggi & 98 & Sedang \\
\hline AYS & 152 & Tinggi & 82 & Rendah \\
\hline PNS & 114 & Sedang & 57 & Sangat rendah \\
\hline GESAP & 132 & Tinggi & 55 & Sangat rendah \\
\hline ET & 127 & Sedang & 72 & Rendah
\end{tabular}


Berdasarkan data di atas, maka perubahan tingkat perilaku membolos pada subjek akan nampak pula secara keseluruhan pada saat pre test dan post test yang dapat dilihat pada gambar berikut:

Gambar 1. Hasil Pre Test dan Post Test Pada Subjek Penelitian

$$
\text { - pree-test } \square \text { post-test }
$$

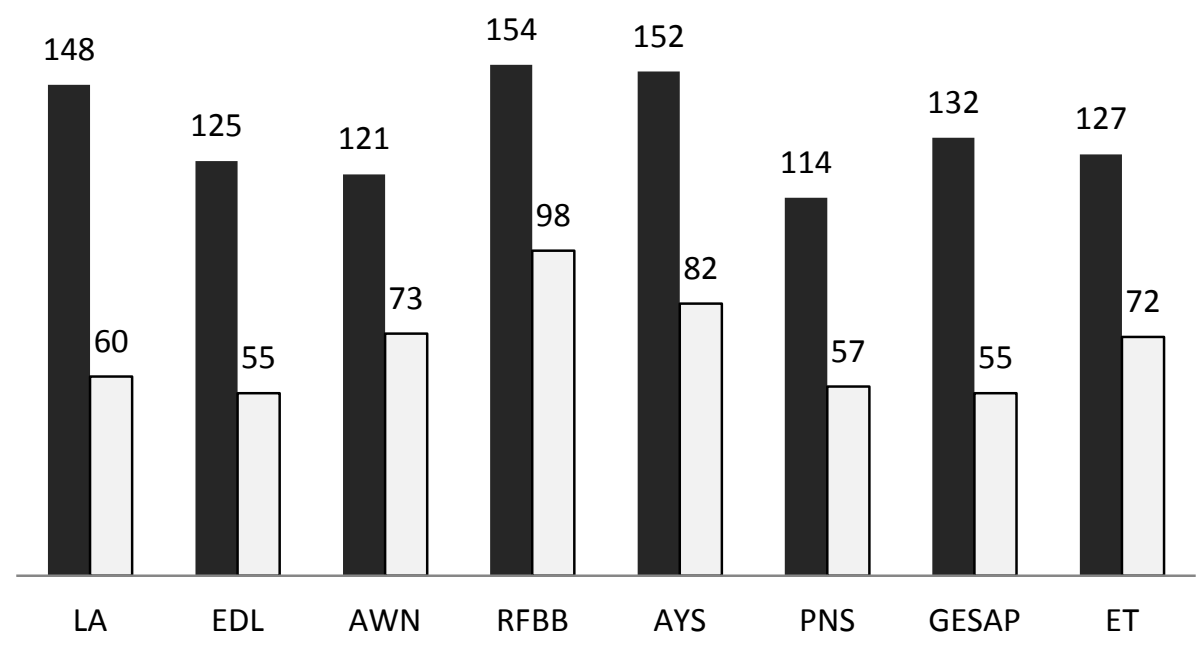

Hasil pre-test dan post-test subjek penelitian sebagaimana gambar 1 di atas, menunjukkan bahwa seluruh anggota kelompok yang terdiri dari 8 siswa yang teridentifikasi sebagai perilaku membolos berada pada kategori tinggi dan sedang dengan rentang 154 sampai 114 setelah diketahui skor perilaku membolos pada saat pre-test, semua anggota kelompok diberikan intervensi berupa konseling kelompok dengan berbantuan teknik problem solving untuk mengurangi perilaku membolos anggota kelompok. Intervensi layanan konseling kelompok dengan berbantuan teknik problem solving dilakukan sebanyak empat kali pertemuan. Setelah intervensi diberikan, terjadi perubahan tingkat perilaku membolos yang ditunjukan oleh anggota subjek penelitian. Perubahan tingkat perilaku membolos dapat diketahui melalui pengukuran yang dilakukan menggunakan skala perilaku membolos dan dilakukan setelah proses pemberian intervensi yaitu berupa posttest. Hasil post-test menunjukkan semua anggota kelompok mengalami penurunan tingkat perilaku membolos dengan perilaku membolos kategori rendah dan sangat rendah dengan skor rentang 98 sampai 55.

\section{Deskripsi Perubahan Terapeutik dan Analisis Diri Subjek}

Penurunan tingkat perilaku membolos siswa pada subjek selain dapat dilihat dari perbedaan skor antara sebelum dan sesudah intervensi, juga ditunjukkan 
oleh perubahan perilaku membolos. Berikut ini dipaparkan deskripsi perubahan terapeutik dan hasil analisis diri masing-masing peserta didik pada subjek.

\section{Siswa $L A$}

Subjek LA pada saat pre test memperoleh skor 148 termasuk dalam kategori tinggi dan pada saat post test LA memperoleh skor 60 termasuk dalam kategori sangat rendah dengan selisih 88 poin. Perolehan skor tersebut menunjukkan bahwa LA terjadi menurunnya terhadap perilaku membolos sehingga dapat mengurangi perilaku membolosnya.

\section{Siswa $E D L$}

Subjek EDL saat pre test memperoleh skor 125 dengan kategori sedang dan pada saat post test memperoleh skor 55 termasuk dalam kategori sangat rendah, sehingga terdapat selisih 70 poin. Artinya terjadi menurun pada diri EDL dalam bertingkahlaku membolos.

\section{Siswa AWN}

Pada saat pre test subyek AWN memperoleh skor 127 yang dikategorikan sedang dan pada saat post test telah memperoleh skor 73 dalam kategori sedang, sehingga terdapat selisih nilai 54 poin. Masih berada dalam kategori sedang namun jumlah skor menurun 11 poin. Artinya terjadi menurunnya tingkat perilaku membolos dan AWN sebagai siswa mampu mengurangi perilaku membolosnya.

\section{Siswa RFBB}

Sewaktu pre test subyek RFBB memperoleh skor 154 dengan kategori tinggi, sedangkan saat post test RFBB setelah diberikan perlakuan memperoleh skor 98 termasuk dalam kategori sedang. Terdapat selisih 56 poin dari dari kategori tinggi menjadi kategori sedang. Artinya terjadi menurunnya tingkat perilaku membolos pada siswa RFBB sehingga mampu mengurangi perilaku membolos pada dirinya.

\section{Siswa AYS}

Subjek AYS pada saat pre test memperoleh skor 152 termasuk dalam kategori tinggi dan pada saat post test memperoleh skor 82 dengan kategori rendah. Terdapat selisih 70 poin. Subyek AYS yang mempunyai perilaku membolos dengan kategori tinggi ternyata mampu menurunnya hingga pada kategori rendah perilaku membolosnya.

\section{Siswa PNS}

Perilaku membolos PNS pada saat pre test memperoleh skor 114 dengan kategori sedang dan pada saat post test PNS memperoleh skor 57 termasuk 
dalam kategori sangat rendah. Hal ini telah terjadi penurunan perilaku membolos PNS yang dibuktikan pada saat pre test memperoleh kategori sedang dan saat post test pada kategori sangat rendah. Artinya PNS mampu menurun perilaku membolos sehingga diharapkan tingkat perilaku membolos dan peserta didik dapat mengurangi perilaku membolosnya.

\section{Siswa GESAP}

Subjek GESAP pada saat pre test memperoleh skor 132 masuk dalam kategori tinggi dan hasil pada saat post test telah memperoleh skor 55 termasuk dalam kategori sangat rendah, sehingga terdapat selisih 77 poin. Dari hasil tersebut berarti terjadi menurun perilaku membolos siswa GESAP, sehingga diharapkan mampu mengurangi perilaku membolosnya.

\section{Siswa ET}

Pada saat pre test subyek ET dengan perolehan skor 127 termasuk dalam kategori sedang dan ketika post test dilakukan setelah dilakukan perlakuan maka diperoleh skor 72 dengan kategori rendah. Dengan demikian perilaku membolos dari subyek ET karena terdapat 55 poin terjadi penurunan dari kategori sedang menjadi kategori rendah. Ini berarti subyek ET mampu menurunkan dan mengurangi perilaku membolosnya.

\section{Pengujian Hipotesis}

Pengujian hipotesis dilakukan dengan statistik paired-sample T Test, pairedsample $T$ Test atau lebih dikenal dengan pre post design dan perhitungannya berbatuan SPSS 20.00. Pre post design adalah analisis dengan melibatkan dua pengukuran pada subjek yang sama terhadap suatu pengaruh atau perlakuan tertentu. Pengukuran pertama dilakukan sebelum diberi perlakuan tertentu dan pengukuran kedua dilakukan sesudahnya. Dasar pemikirannya sederhana, yaitu bahwa apabila suatu perlakuan tidak memberi pengaruh maka perbedaan rataratanya adalah nol (Trihendardi, 2012). Hasil pengujian hipotesis tersebut disajikan pada Tabel 2.

Tabel 2. Paired Samples Statistic

\begin{tabular}{rrrrrr}
\hline & & \multicolumn{1}{c}{ Mean } & N & Std. Deviation & Std. Error Mean \\
\hline Pair 1 & pretest & 134.13 & 8 & 15.226 & 5.383 \\
& posttest & 69.00 & 8 & 15.362 & 5.431 \\
\hline
\end{tabular}

Pada Tabel 2 menunjukkan bahwa perilaku membolos mengalami penurunan rata-rata awal 134.13 menjadi 69.00 dengan jumlah rata-rata 
penurunan sebesar 65.13. Berdasarkan hasil tersebut menunjukkan bahwa kedelapan siswa yang diberikan perlakuan atau treatment mengalami perubahan yang positif antara sebelum dan sesudah treatment yang diketahui dari hasil pembandingan pretest-posttest dan dari diskusi yang berlangsung dalam setiap sesinya. Dengan demikian dapat disimpulkan bahwa para siswa mampu menurunkan perilaku membolos.

Perilaku membolos merupakan perilaku tidak masuk sekolah, meninggalkan sekolah ataupun jam pelajaran sebelum usai yang dilakukan tanpa mendapatkan izin dari sekolah yang dapat disebabkan karena faktor pribadi, keluarga, ataupun sekolah (Handoko, 2013). Perilaku membolos merupakan sebuah reaksi yang dilakukan siswa ketika dia meninggalkan saat-saat jam pelajaran berlangsung sehingga tidak mengikuti proses belajar mengajar di kelasnya. Perilaku tersebut tentunya akan merugikan dirinya sendiri karena ketertinggalan pelajaran, sehingga akan berakibat mengalami kegagalan dan tidak naik kelas. Perilaku membolos mengganggu kegiatan belajar teman-temannya sekelas, akibat lainnya yang tidak baik juga akan terjerumus pada pergaulan bebas dan menyebabkan kerugian pada orang lain akibat dari perilaku yang diluar batas. Kartono (2003) mengemukakan bahwa perilaku membolos berakibat pada dirinya sendiri dan bagi orang lain.

Jensen mengemukakan bahwa kenakalan remaja dibagi menjadi empat jenis yaitu (1) kenakalan yang menimbulkan korban fisik pada orang lain: perkelahian, perkosaan, perampokan, (2) kenakalan yang menimbulkan korban materi: perusakan, pencurian, pemerasan, (3) kenakalan sosial yang tidak menimbulkan korban dipihak orang lain: pelacuran, penyalahgunaan obat, hubungan seks bebas, dan (4) kenakalan yang melawan status misalnya mengingkari status anak sebagai pelajar dengan cara membolos, melawan perintah (Sarwono, 2012).

Dari berbagai perilaku sebagai bentuk dari kenakalan remaja di atas tentunya dipengaruhi oleh berbagai faktor yang melatarbelakangi timbulnya kenakalan tersebut, diantaranya pengaruh yaitu faktor dari keluarga, faktor dari lingkungan sekolah, dan faktor dari dalam individu. Hal ini sesungguhnya secara fungsional dapat dilakukan penilaian bahwa perilaku melarikan diri dari kegiatan pembelajaran dapat dikelola, ada sejumlah treatmen yang mungkin dapat digunakan sebagian dari rencena intervensi perilaku (Geiger, Carr, \& LeBlanc, 2010). Oleh karena itu perilaku membolos ini haruslah segera ditangani dengan sungguh-sungguh karena dapat berpengaruh terhadap prestasi belajarnya, terjadi penyimpangan dari aturan sekolah serta dapat merusak moralitas siswa itu sendiri. 
Dalam usaha intervensi perilaku tersebut dilakukan perlakuan (treatment) dengan berbagai pendekatan atau teknik. Salah satunya dengan pendekatan layanan konseling kelompok dengan teknik problem solving dalam upaya mengurangi perilaku membolos dikarenakan adanya pemahaman diri siswa tentang perilaku membolos yang baru, sehingga siswa mampu membangun tujuan dan solusi dilakukan sebagai perubahan. Kurnanto (2013) menyebutkan bahwa konseling kelompok adalah proses konseling yang dilakukan dalam situasi kelompok, dimana konselor berinteraksi dengan konseli dalam bentuk kelompok yang dinamis untuk memfasilitasi perkembangan individu dan atau membantu individu dalam mengatasi masalah yang dihadapinya secara bersama-sama.

Sebelum intervensi konseling kelompok dengan teknik problem solving dan konseling sebagaimana biasanya diberikan, siswwa diminta mengisi lembar persetujuan mengikuti kegiatan konseling, Siswa diberikan sejumlah informasi yang diperlukan agar mereka dapat membuat pilihan dan memberikan pemantapan untuk melakukan kerja sama lebih aktif antara konselor dan siswa dalam proses konseling. Saat penelitian dilaksanakan, setiap siswa sebagai subjek yang mendapat intervensi berupa konseling kelompok dengan teknik problem solving melaksanakan empat kali pertemuan konseling, durasi waktu konseling kelompok dengan teknik problem solving antara 30-45 menit menyesuaikan fokus dan dinamika kelompok yang terjadi.

Perbedaan tingkat perubahan kecendrungan perilaku membolos pada setiap siswa disebabkan oleh perbedaan kondisi dan situasi pada saat konseling. Kondisi dan situasi yang mempengaruhi antara lain kondisi fisik dan psikis peserta didik. Suasana saat proses konseling berlangsung menentukan kenyamanan peserta didik dalam mengikuti konseling. Selain itu ada beberapa faktor yang tidak terkontrol misalnya sikap-sikap orang dilingkungan keluarga dan juga teman.

Konselor menggunakan teknik-teknik spesifik agar tujuan yang ingin dicapai dalam proses konseling dapat dicapai, dalam membangun solusi, peneliti berusaha untuk mengarahkan peserta didik membuat solusi atau strategi spesifik agar mudah dilaksanakan. Pada percakapan antara konselor dan siswa, konselor memfokuskan pada perubahan, dalam praktiknya konselor menanyakan kepada siswa perubahan apa yang terjadi pada setiap pertemuan. Secara teoritik ini disebut perubahan pra-sesi.

Setelah intervensi, konselor melakukan wawancara konseling. Berdasarkan hasil wawancara dengan siswa pada subjek diperoleh hasil bahwa peserta didik merasa sangat terbantu. Siswa merasakan ada penurunan tingkat perilaku membolos secara bertahap dan pada setiap kali pertemuan. Dari intervensi tersebut disimpulkan bahwa dengan layanan konseling kelompk dengan 
berbantuan teknik problem solving ternyata mampu menurunkan perilaku membolos bagi siswa SMA Negeri 2 Palangkaraya. Hal senada hasil penelitian dari Handoko (2013), Ralasari (2015) dan Tutiona S. dkk. (2016) yang disimpulkan bahwa ternyata dengan konseling kelompok atau konseling individual dengan dengan teknik self management maupun dengan teknik behavior contrac mampu merubah atau menurunkan perilaku membolos siswa.

Dari hasil penelitian ternyata siswa yang berperilaku membolos mampu merubah atau menurunkan perilaku dirinya yang membolos, oleh karena itu konselor, guru dan komponen sekolah lainnya perlu memberikan penguatan secara positif, hal ini diperlukan agar tidak terulang lagi. Indayani et al (2014) dalam penelitiannya tentang penerapan konseling behavioral dengan teknik penguatan positif sebagai upaya untuk meminimalisasi perilaku membolos ternyata efektif sehingga membuat siswa mampu berperilaku positif.

\section{SIMPULAN}

Merujuk dari hasil dan pembahasan penelitian ini sebagaimana ditetapkan dalam tujuan, disimpulkan. Pertama, hasil penelitian mengindikasikan bahwa tingkat perilaku membolos berada pada kategori tinggi dan sedang dengan rentang 154 sampai 114. Setelah intervensi diberikan dan dilakukan pengujian hipotesis dengan statistik paired-sample $T$ Test, maka terdapat adanya perubahan tingkat perilaku membolos yang ditunjukan oleh anggota subjek penelitian. Hasil post-test menunjukkan semua anggota kelompok mengalami penurunan tingkat perilaku membolos dengan perilaku membolos kategori rendah dan sangat rendah dengan skor rentang 98 sampai 55. Penurunan tingkat perilaku membolos siswa pada subjek selain dapat dilihat dari perbedaan skor antara sebelum dan sesudah intervensi, rata-rata awal 134.13 menjadi 69.00 dengan jumlah rata-rata penurunan sebesar 65.13.

Berdasarkan pembahasan hasil dan kesimpulan dari penelitian ini, maka disarankan bahwa layanan konseling kelompok dengan berbantuan teknik problem solving dapat diterapkan dalam berbagai setting pada dunia pendidikan sebagai salah satu bentuk pelayanan bimbingan dan konseling secara komperehensif disekolah. Sehingga dapat digunakan oleh lembaga pendidikan, lembaga sosial yang berkepentingan dalam pembinaan remaja, konselor sekolah, civitas akademika diprogram studi bimbingan dan konseling serta peneliti selanjutnya. 


\section{REFERENSI}

Badarudin. (2011). Materi bahan ajar kuliah: Bimbingan dan konseling di sekolah dasar. (Unpublished teaching materials) Universitas Muhammadiyah Purwokerto, Indonesia.

Damayanti, F. A., \& Setiawati, D. (2013). Studi tentang perilaku membolos pada siswa SMA swasta di Surabaya. Jurnal Bimbingan dan Konseling UNESA, 3(1), 454-461.

D'zurilla, T. J., \& Goldfried, M. R. (1971). Problem solving and behavior modification. Journal of Abnormal Psychology, 78(1), 107-126.

Geiger, K. B., Carr, J. E., \& LeBlanc, L. A. (2010). Function-based treatments for escape-maintained problem behavior: A treatment-selection model for practicing behavior analysts. Behavior Analysis in Practice, 3(1), 22-32.

Handoko, A. (2013). Mengatasi perilaku membolos melalui konseling individual menggunakan pendekatan behavior dengan teknik self management pada siswa kelas X Tkj SMK Bina Nusantara Ungaran tahun ajaran 2012/2013. (Unpublished undergraduate's thesis) Universitas Negeri Semarang, Indonesia.

Ichsani, W. (2007). Studi tentang faktor dan alternatif penyelesaian masalah perilaku membolos pada siswa SMA Negeri 1 Teras Boyolali tahun Ajaran 2006/2007. (Unpublished undergraduate's thesis) Universitas Sebelas Maret, Indonesia.

Indayani, A., Sedanayasa, G., Antari, N. N. M., \& Erg, M. (2014). Penerapan konseling behavioral dengan teknik penguatan positif sebagai upaya meminimalisasi perilaku membolos pada siswa kelas X.1 SMA Negeri 1 Sawan tahun ajaran 2013/2014. Jurnal Ilmiah Bimbingan Konseling, 2(1), 110.

Kartono, K. (2003). Bimbingan bagi anak dan remaja yang bermasalah. Jakarta: Rajawali Press.

Kartono, K. (2014). Kenakalan remaja. Jakarta: Rajagrafindo Persada.

Kurnanto, M. E. (2013). Konseling kelompok. Bandung: Alfabeta. 
Mahmudah. (2013). Mengurangi perilaku membolos siswa dengan menggunakan layanan konseling behavior. KES, 1(1).

Majid, A. (2012). Perencanaan pembelajaran mengembangkan standar kompetensi guru. Bandung: Remaja Rosdakarya.

Nurihsan, A. J. (2006). Bimbingan dan konseling dalam berbagai latar kehidupan. Bandung: Refika Aditama.

Ralasari, T. M. (2015). Upaya pengubahan perilaku membolos siswa melalui layanan konseling kelompok dengan model CBT. Jurnal Penelitian Tindakan Bimbingan \& Konseling, 1(1), 42-47.

Rosidah, A. (2016). Bimbingan kelompok melalui teknik problem solving untuk meningkatkan penyesuaian diri siswa terisolir. Jurnal Bimbingan dan Konseling, 2(2), 136-143.

Sarwono, S. W. (2010). Psikologi remaja (Ed rev.). Jakarta: Raja Grafindo Persada.

Setiawan, M. A. (2015). Model konseling kelompok dengan teknik problem solving untuk meningkatkan self-efficacy akademik siswa. Jurnal Bimbingan Konseling, 4(1), 8-14.

Sohrabi, R., Mohammadi, A., \& Aghdam, G. A. (2013). Effectiveness of group counseling with problem solving approach on educational self-efficacy improving. Procedia-Social and Behavioral Sciences, 84, 1782-1784.

Sugiyono. 2013. Metode penelitian pendidikan (Pendekatan kuantitatif, kualitatif dan $R \& D)$. Bandung: Alfabeta.

Suparmanto. (2014). Penerapan metode problem solving untuk meningkatkan keaktifan dan prestasi belajar siswa di smk muhammadiyah 1 bantul. Yogyakarya: Universitas Negeri Yogyakarta.

Sukardi. K. D. (2008). Pengantar pelaksanaan program bimbingan dan konseling di sekolah. (Edisi revisi). Jakarta: Rineka Cipta. 
Efektivitas Layanan Konseling Kelompok Menggunakan Teknik Problem Solving

Dalam Menurunkan Perilaku Membolos Siswa

Trihendra, C. (2012). Step by step SPSS analisis data statistik. Yogyakarta: Penerbit Andi.

Tutiona, M. Y., Munir, A., \& Ratu, B. (2016). Upaya mengurangi perilaku membolos melalui konseling individual dengan teknik behavior contract pada siswa SMP Negeri 6 Palu. Jurnal Konseling dan Psikoedukasi, 1(1), 69-78.

Yusuf, S. (2014). Psikologi perkembangan anak dan remaja. Bandung: Remaja Rosdakarya. 